Article

\title{
Remembering Thomas Becket in Saint-Lô
}

\author{
Alyce A. Jordan
}

check for

updates

Citation: Jordan, Alyce A. 2021. Remembering Thomas Becket in Saint-Lô. Arts 10: 67. https:// doi.org/10.3390/arts10030067

Academic Editor: Carles Sánchez Márquez

Received: 10 July 2021

Accepted: 10 September 2021

Published: 14 September 2021

Publisher's Note: MDPI stays neutral with regard to jurisdictional claims in published maps and institutional affiliations.

Copyright: (C) 2021 by the author. Licensee MDPI, Basel, Switzerland. This article is an open access article distributed under the terms and conditions of the Creative Commons Attribution (CC BY) license (https:/ / creativecommons.org/licenses/by/ $4.0 /)$.
Department of Comparative Cultural Studies, Northern Arizona University, Flagstaff, AZ 86001, USA; alyce.jordan@nau.edu

\begin{abstract}
France numbered second only to England in its veneration of the martyred archbishop of Canterbury. Nowhere in France was that veneration more widespread than Normandy, where churches and chapels devoted to Saint Thomas, many embellished with sculptures, paintings, and stained-glass windows, appeared throughout the Middle Ages. A nineteenth-century resurgence of interest in the martyred archbishop of Canterbury gave rise to a new wave of artistic production dedicated to him. A number of these modern commissions appear in the same sites and thus in direct visual dialogue with their medieval counterparts. This essay examines the long legacy of artistic dedications to Saint-Thomas in the town of Saint-Lô. It considers the medieval and modern contexts underpinning the creation of these works and what they reveal about Thomas Becket's enduring import across nine centuries of Saint-Lô's history.
\end{abstract}

Keywords: Thomas Becket; Normandy; Saint-Lô; Coutances; Bayeux; Mont-aux-Malades

\section{Introduction}

Veneration of Thomas Becket spread rapidly across Europe and beyond in the wake of his dramatic murder in 1170 and canonization in 1173. France, the country that had protected the archbishop during his long exile, a fact he acknowledged with his dying breath in commending his soul to God, the Virgin Mary, and Saint Denis, espoused a devotional fervor second only to that of England. Nowhere in France was veneration of Thomas Becket more ubiquitous than Normandy, a region which, at the time of his canonization, comprised part of Henry II's Anglo-Norman Empire (Foreville 1973, 1975; Fournée 1995; Nilgen 2000) (Figure 1). The sources of this devotion are myriad: Becket's parents were both Norman by birth, and Henry II established many of his penitential foundations to Becket in Normandy. Visual testimony to Becket's cult survives in the numerous medieval and modern works of art dedicated to him (Webster 2016; Slocum 2019).

This essay explores the devotion to Thomas Becket in Normandy and its articulation in the visual culture of the region using, as a case study, the town of Saint-Lô, today located in the département of La Manche. Saint-Lô boasted one of the earliest dedications to Thomas Becket, a church consecrated in 1174 and has sustained a continuous chain of ecclesiastical and artistic dedications to the archbishop up to the present day (Figures 2-18). While neither the original Saint Thomas church nor its seventeenth-century successor survives, the details of their founding and suppression speak to Becket's significance in medieval and early modern Normandy. The nineteenth-century dedication of a chapel to Saint Thomas in Notre-Dame de Saint-Lô bespeaks Becket's sustained importance up to the present day. I examine a succession of artistic works, a painting and two narrative stained-glass windows, which have decorated the chapel over the past two centuries and attempt to situate each within a temporal context. This exceptional visual continuum of buildings and artworks, created in one town over a span of eight centuries, enables an exploration of the ways in which Saint Thomas was invoked in response to a diverse trajectory of historical exigencies. Much of this modern imagery is unique in the corpus of Becket iconography, thereby demonstrating how Thomas's exceptional life, death, and legacy continued to inspire 
artists and patrons long after the Middle Ages. At the same time, thematic recurrences in the two Becket windows prompt consideration of the saint's broader and lasting import to a region now widely considered French, but which came to prominence in the medieval period as the epicenter of Henry II's cross-Channel, Anglo-Norman empire. Today Henry II is primarily situated within the history of England's kings, and his one-time chancellor Thomas, who died archbishop of Canterbury, within the realm of English saints. The profusion of medieval dedications and artworks devoted to Thomas Becket in medieval Normandy and the resurgence of Norman Becket commissions in the nineteenth century, however, suggest that, in this region, it was Thomas's Norman history and ancestry that comprised the more compelling aspects of his saintly identity.

\section{The Lives of Thomas Becket in the Arts of Saint-Lô}

According to local tradition, archbishop Thomas, passing through Saint-Lô on his return to Canterbury in 1170, saw a church under construction and asked to whom it would be dedicated. When the masons replied that they did not know, Thomas proposed it should honor the first new martyr to shed his blood for Jesus Christ. Interpreted as a prophecy of the archbishop's own death just weeks later, the church was duly dedicated to Saint Thomas in 1174 (Toustain de Billy 1912, pp. 29-32, 230-32; LeClerc 1932). Writing in the late seventeenth-century, René Toustain de Billy states that he would not include such a fantastical origin story had he not read it in a Latin poem recounting the history of Saint-Lô, scribed by Guillaume Ybert, a learned contemporary (p. 30). Reginald fitz Jocelin, bishop of Bath, and the nephew of Saint-Lô's diocesan bishop, Richard de Bohun, bishop of Coutances, presided over the church's 1174 consecration (Spear 1998, p. 214). While Richard of Coutances may simply have been calling in a family favor when he tapped Reginald of Bath to dedicate Saint-Lô's new church, his choice must certainly have garnered some attention. Reginald fitz Jocelin had been a member of archbishop Thomas's household, but left his service when Thomas fled to France (Barlow 1986, pp. 78, 131). In 1167, Reginald, then archdeacon of Salisbury, was among the party of envoys who traveled to Rome on Henry II's behalf, and he remained actively involved in the dispute as an advocate for the king over the following three years (Barlow 1986, pp. 175, 189-92). By 1169, Reginald's efforts in support of Henry's position prompted Thomas to threaten him with excommunication, describing Reginald, in a letter to his own papal nuncios, as "that bastard, fornicator, enemy of peace in the church and son of a priest" (a reference to bishop Richard de Coutances's brother Jocelin de Bohun, bishop of Salisbury, whom Thomas considered an inveterate enemy) (quoted in Barlow 1986, p. 192). Reginald retained his post as royal legate after the murder. Having by then become a favorite of both Henry and pope Alexander III, Reginald helped broker the terms and choreography of Henry's 1172 reconciliation ceremonies in Avranches and Caen (Barlow 1986, pp. 260-61). Two years later he succeeded his father as bishop of Bath. ${ }^{1}$

Bishop Reginald's involvement in the Becket dispute, together with the church's prodigious scale, the latter all but necessitating that its construction had begun years before Thomas's 1173 canonization, would have fueled belief in its origin story. Built on the Champ de Mars, also known as the Champ Saint Thomas, Saint-Thomas's size $(43 \times 20 \mathrm{~m})$ and strategic location, adjacent to the chateau and the town ramparts, made it a nexus of conflict during the 100 Years' War and the Wars of Religion. Severely damaged by the Huguenots in 1562, the church was torn down in 1592 (Toustain de Billy 1912, pp. 91-92, 134-35, 392; LeClerc 1932, pp. 10-11; Delauney 1864, pp. 85-87, 111-12) (Figure 2). Having bitterly opposed the destruction of their medieval edifice, Saint-Thomas's parishioners proposed the erection of a new church elsewhere in the town. Plans for Saint-Lô's second Saint-Thomas church began in 1608 and, in 1630, the inaugural mass was celebrated in the choir (LeClerc 1932, pp. 11-15; Toustain de Billy 1912, pp. 146, 431-34). This SaintThomas church was deconsecrated in 1811, a casualty of the French Revolution. Employed alternately as a theater, a granary, and a fledgling museum, the structure was finally demolished in 1895 (LeClerc 1932, pp. 15-17) (Figures 2 and 3). ${ }^{2}$ Its memory, however, 
survives in the eponymous rue Saint Thomas, which runs adjacent to the church's former site, and, more significantly, in the immediate 1811 dedication of the Saint Thomas chapel in the church of Notre-Dame de Saint-Lô. Built during the 1420 extension of the nave, and long dedicated to Saint George (LeClerc 1932, pp. 39-40), ${ }^{3}$ the newly dedicated Saint Thomas chapel inherited from the defunct Saint-Thomas church, its high altar, along with Becket relics, encased "in reliquaries ... attached to the [altar's] woodwork" (No Author 1936, pp. 158-59; Delauney 1864, p. 130) (Figures 2, 4 and 5). ${ }^{4}$ Notre-Dame was situated just southeast of the chateau (Figure 2). The selection of Notre-Dame as the new locus for Becket's veneration may have been informed by its geographic proximity to the original, twelfth-century Saint-Thomas church.

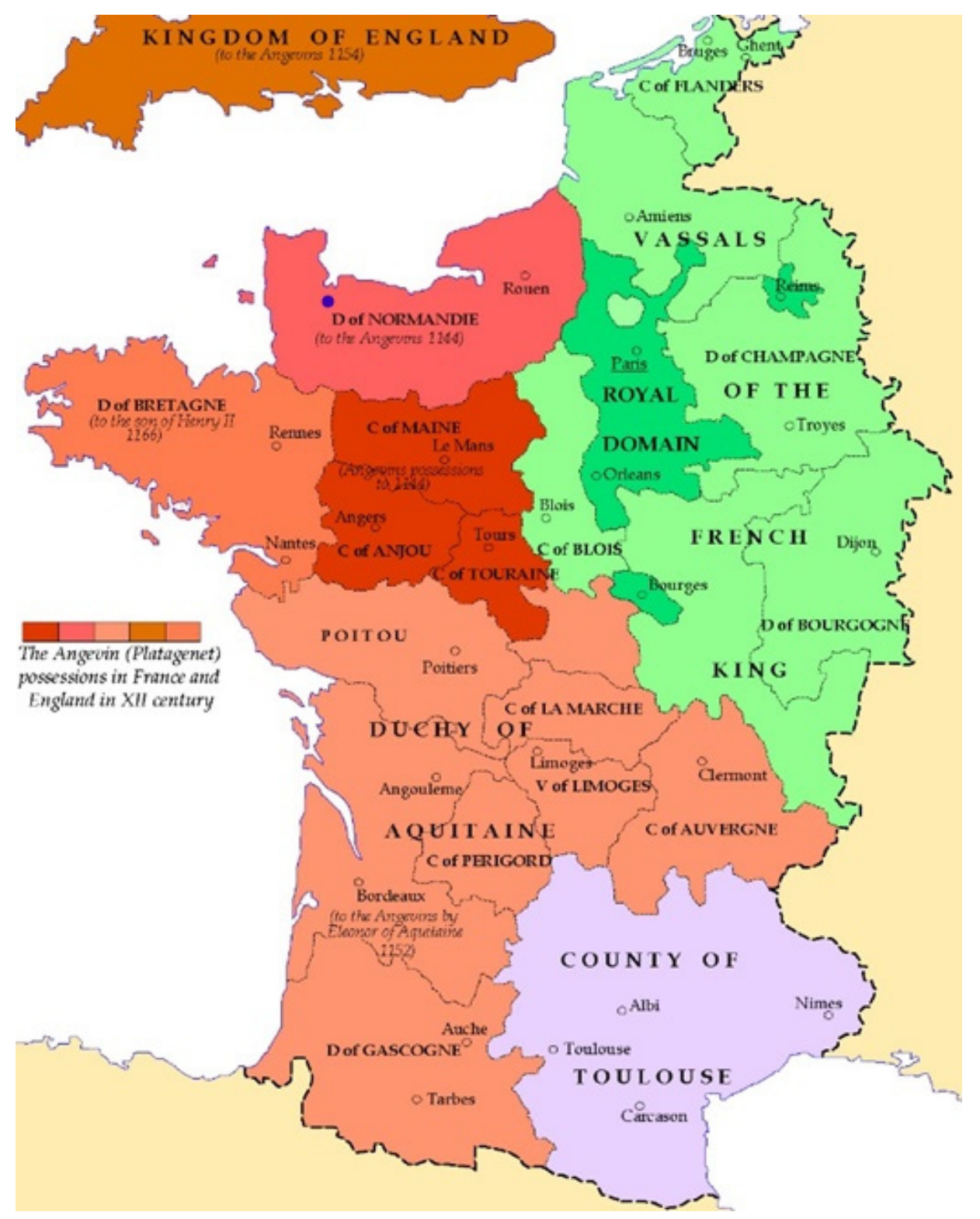

Figure 1. Map of the Angevin Empire's continental holdings during the twelfth and thirteenth centuries. The blue dot indicates Saint-Lô's location in Normandy. Wikipedia Commons. https: / / commons.wikimedia.org/wiki/File:France_1154_Eng.jpg (accessed on 12 September 2021). 




Figure 2. Map of Saint-Lô with red crosses showing the former locations of churches dedicated to Saint-Thomas on the Champ de Mars and the rue Saint Thomas and a blue cross indicating the location of Notre-Dame de Saint-Lô. (C) adapted by author from Plum (1994).

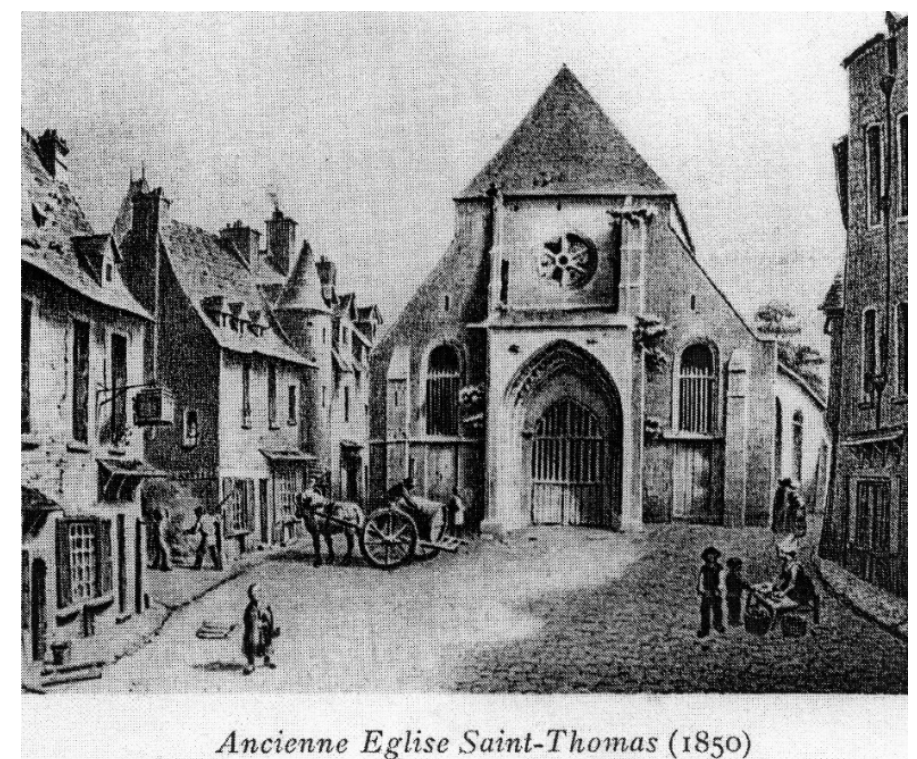

Figure 3. Saint-Lô, Saint-Thomas Church, deconsecrated 1811, demolished 1895. (c) Toustain de Billy 1912, opposite p. 224 (image in the public domain).

A window containing six trefoil lancets culminating in elaborate tracery decorates the chapel above the altar. Empty in 1811, its original glass may have been lost during the Protestant sack of Saint-Lô in 1562, at which time the destruction of numerous lancets and general pillaging of the church were recorded. ${ }^{5}$ Repair of the damaged windows began only after the French Revolution. The aperture above the altar in the Becket chapel appears to have remained undecorated, however, since an 1864 description of the church's stained glass by Abbé Delauney, then vicar of Notre-Dame, makes no mention of it. The Abbé 
does, however, describe a painting then serving as the chapel's altarpiece (Delauney 1864, pp. 120-21).

In contrast to the short, prosaic summaries of Notre-Dame's other decorations, Delauney's analysis of this work proves worthy of a connoisseur and enabled me to identify the painting, currently in storage at the Musée Quesnel-Morinière in nearby Coutances (Figure 6). Executed circa 1850, by Basile Quesnel, a revered, regional painter, and measuring $2.42 \mathrm{~m}$ high, the Martyrdom of Archbishop Thomas would have composed an affecting backdrop to the chapel's altar, while also serving to obscure much of the undecorated window. ${ }^{6}$ Despite his reputation as an academic painter, Quesnel's romanticized rendition of the murder exhibits many compositional elements redolent of Counter-Reformation painting. Set in a closely-cropped, indeterminate space, Thomas, clad in full episcopal attire, collapses backward, one foot illusionistically projecting over a stone step, his arms positioned in a dynamic baroque diagonal. The soon-to-be martyr casts his eyes upward, past the grimacing visage of his attacker towards the shaft of divine light that breaks through the heavens. One knight prepares to plunge his sword into Thomas's heart, while a second wields an ax over his head. Thomas's body fills the foreground; the imposing form of his primary assailant, and the cropped figure of the ax-wielding accomplice, effectively obscure the background, imparting a "you are there" immediacy to the scene. In the painting's original location, Thomas's foot would have appeared almost to touch the altar, heightening the scene's drama and Christological parallels. Executed circa mid-century, ${ }^{7}$ this rendering of Becket's martyrdom reverberates with still-fresh memories of the French Revolution and the many atrocities visited upon churches and clergy alike. In the particular context of Saint-Lô, the painting would have reminded viewers of the demise of the town's original church of Saint-Thomas, and the revolutionary suppression of its successor church, even as it visually reified the archbishop's continued veneration in the Saint-Thomas chapel of Notre-Dame.

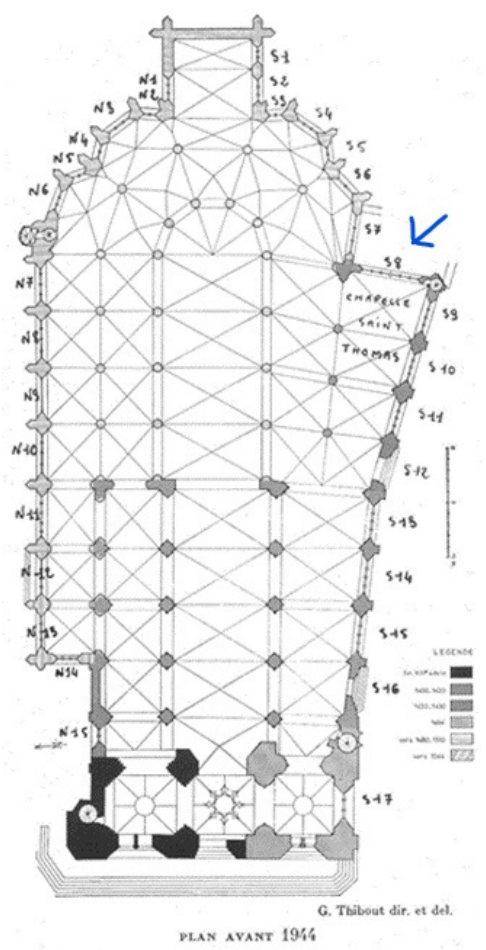

Figure 4. Saint-Lô, Church of Notre-Dame, plan showing location of the former Saint George chapel, rededicated to Saint Thomas in 1811. The Saint Thomas window appears above the altar and is identified as S8 on the plan. Photo: G. Thibout (image in the public domain). 




Figure 5. Saint-Lô, Church of Notre-Dame, Saint-Thomas chapel towards the southeast. The Saint Thomas window appears above the altar in the chapel's eastern wall. (C) author.



Figure 6. Basile Quesnel, Murder of Thomas Becket, circa 1850, oil/canvas, N INV. 939.P.67, Musée Quesnel-Morinière, Coutances. (C) musée Quesnel-Morinière, Coutances. (with kind permission). 
Abbé Delauney's analysis offers some clues as to the painting's current inauspicious location. ${ }^{8}$ The Abbé observed that the artist had made Thomas "too old", considering he was "only 53" at the time of his murder, while conceding that the rigors of his exile could have caused the archbishop to grey prematurely (Delauney 1864, p. 120). Delauney reserved the bulk of his critique, however, for the rendering of Becket's attackers, asking rhetorically if such exaggerated expressions, wild eyes, and histrionic gestures were really necessary to kill "a defenseless old man". Our cleric-turned-art critic concludes by asserting that even in the depiction of such a heinous crime, the painter could have had his actors "retain some trait recalling the nobility of their origin," an assessment demonstrating Delauney's awareness that all four assailants were high-born knights of prominent Norman lineage. ${ }^{9}$

The Becket chapel finally received a new window in 1898, executed by the prolific, gothic-revival glazier Félix Gaudin. ${ }^{10}$ This long-delayed restoration, however, proved short lived. Gaudin's window, along with much of the town itself, was pulverized in the June 1944 bombardment of Saint-Lô. I have reconstructed the window's iconography from verbal descriptions, pre-war photographs of the Becket chapel, and the fortuitous acquisition of a previously unknown print recently discovered on eBay (Figure 7). ${ }^{11}$ The window's composition mirrored that of Notre-Dame's surviving fifteenth- and sixteenth-century glass, comprising three large scenes disposed across six lancets in the upper register and six small-scale panels forming a predella below. The upper register depicts Henry II entrusting the education of his son, Prince Henry, to Chancellor Thomas (Barlow 1986, pp. 41-63; Duggan 2004, pp. 16-22), followed by Thomas, the archbishop, exiled in France and dressed in monastic garb, conversing with Pope Alexander III. ${ }^{12}$ In the last scene, the Virgin Mary gifts Thomas a red chasuble, symbolic of his impending martyrdom. ${ }^{13}$ The predella panels depict Thomas's consecration, followed by two scenes of archbishop Thomas conversing with the monks of Canterbury, or perhaps, Pontigny. ${ }^{14}$ The following scenes depict Thomas bowing before Alexander III, the saint's murder, and Henry II, nude to the waist, kneeling on the steps of a church in an attitude of penance, before a group of bishops (Barlow 1986, pp. 244-50; Duggan 2004, pp. 201-13; Staunton 2001, pp. 215-17). Gaudin's rich imagery is remarkable on several fronts and worthy of a separate study. I focus here on a select number of elements pertinent to the window's immediate geographic and temporal contexts. Images of Becket's life prior to his consecration are extremely rare, and the miraculous appearance of the Virgin gifting a chasuble to Thomas is, to my knowledge, unprecedented in Becket iconography. These images, however, relate in striking ways both to significant events in late-nineteenth-century France and to Norman history.

The opening scene offers a visual shorthand of Thomas's intimate relationship with his sovereign and his eight-year career as Henry's chancellor, most of which transpired on Norman soil (Barlow 1986, pp. 41-63; Duggan 2004, pp. 16-22; Staunton 2001, pp. 48-61; Petit 1999; Nilgen 2000, pp. 189-204) (Figure 8). By extension, the scene recalls Thomas's own Norman ancestry and the import of Normandy itself as the nexus of the former Plantagenet empire. The window's final predella panel, in its seeming conflation of Henry's penitential acts, offers a coda to Normandy's centrality in the Becket drama. This image simultaneously conjures memories of the king's 1172 purgation and reconciliation before the doors of Avranches cathedral in the presence of Alexander III's papal legates, that ceremony's high-profile reenactment in Caen days later before French and Norman prelates, and his public penance at Canterbury two years later, where Henry beseeched Thomas's aid in the widespread insurrection spearheaded by his son, the young king (Barlow 1986, pp. 259-62; Duggan 2000, pp. 655-57; 2004, pp. 221-23). Henry II's subsequent and stunning 1174 victory cemented the reconciliation of saint and king, and secured Thomas's status as special protector of the Plantagenet realm (Barlow 1986, pp. 269-70; Duggan 2004, pp. 254-55). 




Figure 7. Saint-Lô, Church of Notre-Dame, Saint-Thomas chapel, print reproduction of the Life of Saint Thomas window, 1898, Félix Gaudin, glazier, window destroyed 1944. (C) unknown (image in the public domain).

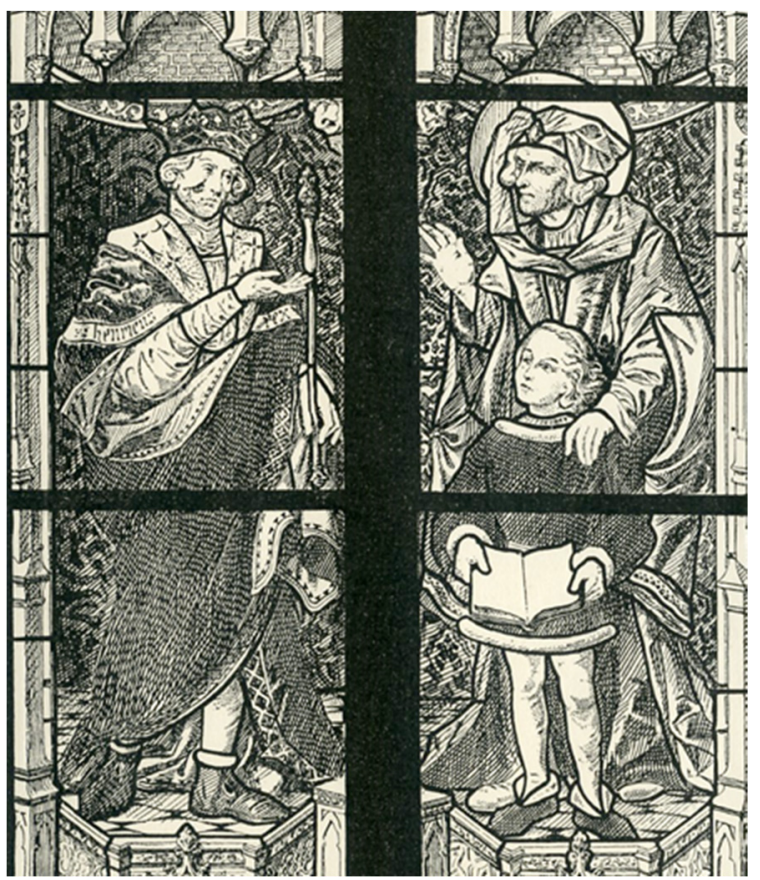

Figure 8. Saint-Lô, Church of Notre-Dame, Saint-Thomas chapel, Life of Saint Thomas window, 1898, detail, Henry II charges Thomas with the education of Prince Henry. (C) unknown (image in the public domain). 




Figure 9. Saint-Lô, Church of Notre-Dame, Saint-Thomas chapel, Life of Saint Thomas window, 1898, detail, Mary gifts Thomas a chasuble. (C) unknown (image in the public domain).

Mary's gifting of a chasuble to archbishop Thomas has no direct counterpart in Becket hagiology (Figure 9). The most famous recipient of a chasuble from the hands of the Virgin is Saint Ildephonsus, a seventh-century archbishop of Toledo (Poncelet 1910). However, miraculous occurrences involving Thomas and articles of clothing were common in the Middle Ages. The most famous of these appears in the Golden Legend and recounts the story of the Virgin mending Thomas's hairshirt (Voragine 1993, vol. 1, p. 61). William Caxton's version of the Golden Legend additionally relates that Thomas said mass before pope Alexander III wearing a white chasuble. Becket told the pope that the chasuble would turn red when he became a martyr. The pope kept the vestment and, upon its turning red, had a requiem mass sung for the archbishop, during which an angel appeared singing Laetabitur Justus, the beginning of the liturgical office for martyrs (Ellis [1483] 1910, vol. 2, pp. 192, 196). Rachel Koopmans identified this latter miracle in a sixteenth-century Becket window from Saint Michael-le-Belfrey in York (Koopmans 2014, pp. 1062-64, Figure 23). The late medieval Saga of Archbishop Thomas, an Icelandic text whose nineteenth-century translation into English made new details of Becket's life accessible to a wider audience, describes an event organized by Thomas's fellow students during his tenure in Paris, at which each of them was to display a piece of needlework executed by their beloved. The chaste young Thomas, whose thoughts and devotions focused solely upon the Virgin, beseeched Mary to provide him with some scrap of needlework so as to spare him from the ridicule of his peers. The Virgin's response came in the form of a small ivory casket which, when opened, miraculously revealed a complete set of episcopal regalia, replete with crozier (Magnússon [1875] 2012, vol. 1, pp. 20-25). ${ }^{15}$

Pieces of Thomas's clothing, including his hairshirt, were initially gifted by Canterbury monks to the faithful poor and later to important patrons and fellow ecclesiastical institutions. Myriad examples of vestments associated with Saint Thomas, many still venerated as relics, survive across Europe (Koopmans 2020; Shalem 2016). While the scene in Gaudin's window shares some resonance with the Icelandic Saga miracle, and the chasuble's red color with the story in Caxton's Golden Legend, Mary's depiction here, poised upon a bed of clouds and minus the Christ child, also visually recalls the Virgin of the Immaculate Conception (Holweck 1910). ${ }^{16}$ Following centuries of debate, the Doctrine of the Immaculate Conception finally received papal approbation in 1854. The Doctrine's proclamation by Pope Pius IX was a source of great joy in Normandy, where the Virgin 
Immaculata had long been a focus of ardent devotion. As early as 1070, the bishop of Coutances, Geoffroy de Montbray, had dedicated a chapel to the Virgin Immaculata in his cathedral. And the nineteenth-century bishop of Coutances, Jacques-Louis Daniel, credited his diocese with initiating European celebration of the Immaculate Conception, declaring that the feast could rightly be called "la fête des normands" (Daniel 1855, p. 5). The chasuble comprises the "principal and most conspicuous" element of liturgical regalia worn by Roman Catholic priests during the mass (Thurston 1910). Juxtaposed with the image of Pope Alexander III in the neighboring lancet, this scene conjured a powerful encomium to Church authority and ultramontane allegiance, by rendering miraculous the vestment which Nicholas Vincent, discussing the 1840s reappearance of the chasuble in Anglican liturgical garb, vividly described as "that reddest of red popish rags" (Vincent 2016, p. 103). Additionally, it declared the particular piety of the Norman people, while also effecting a deft linkage between Saint Thomas and the "marian fever" that enveloped late-nineteenth-century France (Kselman 1983; Byrnes 2005).

The Saint Thomas chapel window remained empty from 1944 until 1968, when the current ensemble, executed by the atelier of Max Ingrand, was installed (Blin 2017) (Figure 10). Ingrand's window thus marks the third instance of Thomas's pictorial veneration in NotreDame de Saint-Lô and the latest iteration of the Becket imagery that must certainly have also decorated Saint-Lô's earlier Becket churches. Its six lancets again comprise two registers with large-scale images disposed above small-scale panels. This narrative begins in the predella, the opening scenes of which again recall Thomas's career as Henry II's chancellor. In the first image, Thomas, on horseback, engages his passion for hunting, his hawk held aloft on his right hand, his dog running alongside (Barlow 1986, pp. 25, 50, 55; Duggan 2004, pp. 10-11; Staunton 2001, pp. 43, 50). The following panel records Chancellor Thomas's military exploits on Henry's behalf in Aquitaine and the Vexin, his allegiance underscored by the prominent display of Anglo-Norman heraldry on his shield (Barlow 1986, pp. 50, 57-58, 61-62; Duggan 2004, pp. 19-21; Staunton 2001, pp. 13, 57-59). Thomas's investiture as archbishop of Canterbury and his impassioned defense of Church rights at Northampton occupy the central lancets. The following scene of Thomas aboard ship denotes his flight across the Channel to France in 1164, and the last panel, the final meeting of king and prelate at Fréteval (Barlow 1986, pp. 208-12; Duggan 2004, pp. 183-86; Staunton 2001, pp. 174-77).

In the upper register, the archbishop's Becket's murder follows swiftly on the heels of his joyful return to Canterbury. The central panels depict Christ presenting a kneeling Thomas to God the Father, while a kneeling Henry II does penance for Becket's murder. The final lancet includes four figures surrounding a small-scale structure at whose door Saint Thomas stands. This narrative, much of it again unprecedented, presents a worthy successor to Gaudin's window and a counterpoint to the varied Becket biographies found in medieval art. The diversity of medieval Becket iconography evinced the degree to which the archbishop's sainthood had been unanticipated and unscripted (Borenius 1932; Brisac 1975; Jordan 2016). The persistence of such diversity in these modern iterations bespeaks, I believe, a desire to spotlight Thomas's Norman connections and, by extension, Saint-Lô's own Norman culture. 


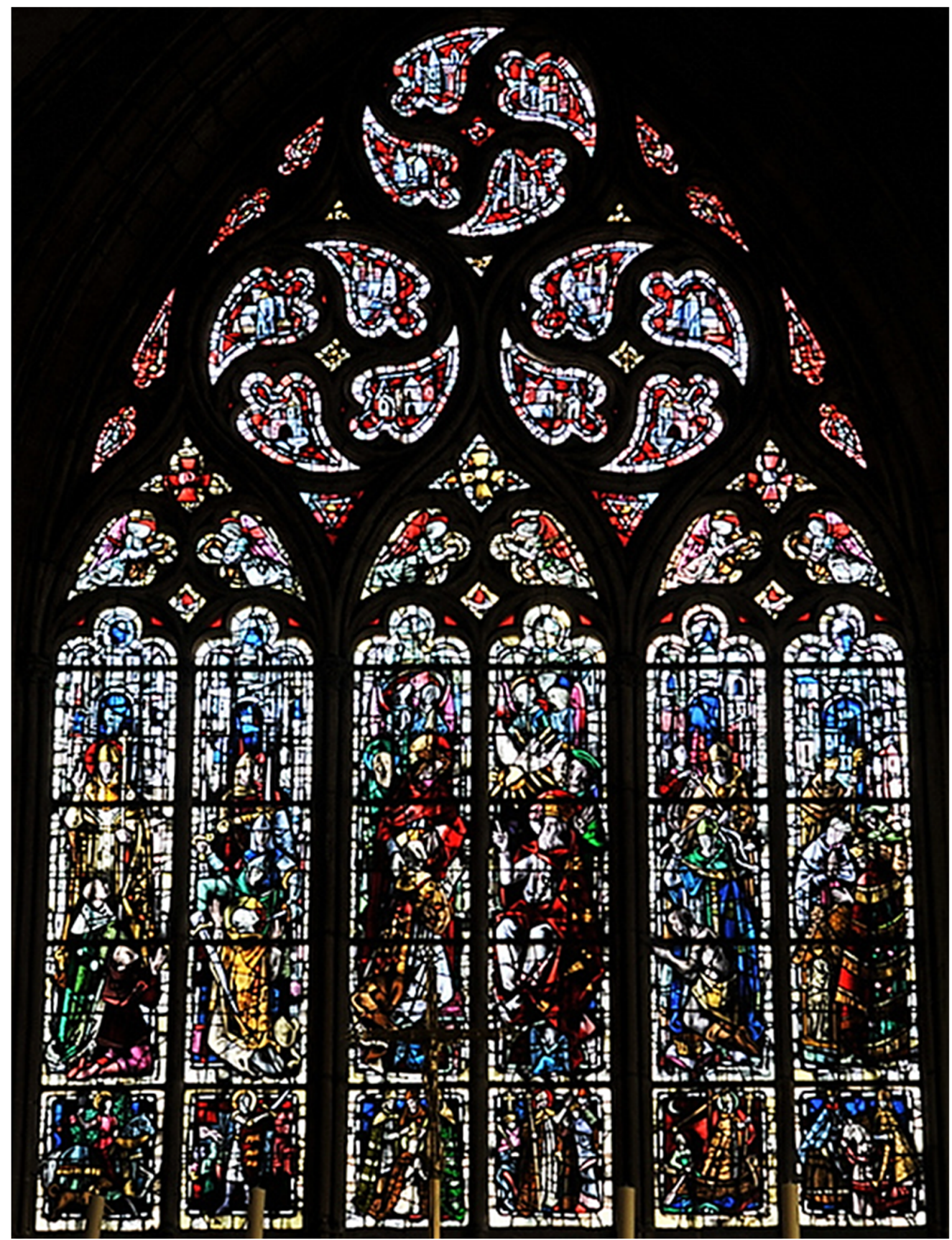

Figure 10. Saint-Lô, Church of Notre-Dame, Saint-Thomas chapel, Life of Saint Thomas window, 1968, Max Ingrand, glazier. (C) author.

As in Gaudin's 1898 window, this window emphasizes Becket's secular career as Henry II's chancellor. Thomas's prowess as a hunter and military leader prefigures his later, and equally muscular, defense of Church rights, an image echoed in the equestrian staging of Thomas and Henry's final meeting at Fréteval (Figures 11-13). The Plantagenet heraldry displayed on Thomas's shield—so like Normandy's modern heraldic insigniatelescopes medieval and modern Norman identity (Figures 12 and 14). Visual panegyrics to Church authority fill the upper register, in the juxtaposition of Thomas's murder and Henry's penance, a scene again indicative of Henry's public acts of atonement before clergy in Avranches, Caen and, ultimately, Canterbury. Like Gaudin's window, compositional parallels in the rendering of Thomas's murder and Henry's penance-the kneeling pose, the wielding of swords and whips, the foregrounding of miter and crown-make clear that it was precisely Thomas's triumph in death that proclaimed the rightness of his cause 
and Henry's supplication that secured Thomas as the special protector of the Plantagenet kingdom. (Figures 15 and 17). One might extend the parallelism of Henry and Thomas's poses and headgear to a broader consideration of the ways in which these two panels interact with the central scene of Christ presenting Thomas to God (Figures 15-17). God the Father wears an elaborate Crown, Christ, an equally elaborate Crown of Thorns. Christ gently places his hands on either side of Thomas's head, almost as if he were presenting exactly that part of Thomas's body which was severed in his brutal murder. Indeed, God's crown, Christ's Crown of Thorns, and Thomas's highlighted corona form a visual triumvirate, a counterpart to the Trinity itself, realized in the presence of the dove-the Holy Spirit_-positioned on a powerful diagonal with Thomas's raised head. Collectively, the four central lancets present a symbolic play of crowns and corona which, in their visual sophistication, comprise a worthy counterpart to the textual dexterity with which Thomas's biographers engaged these same two words (Hayes 2004, p. 200).

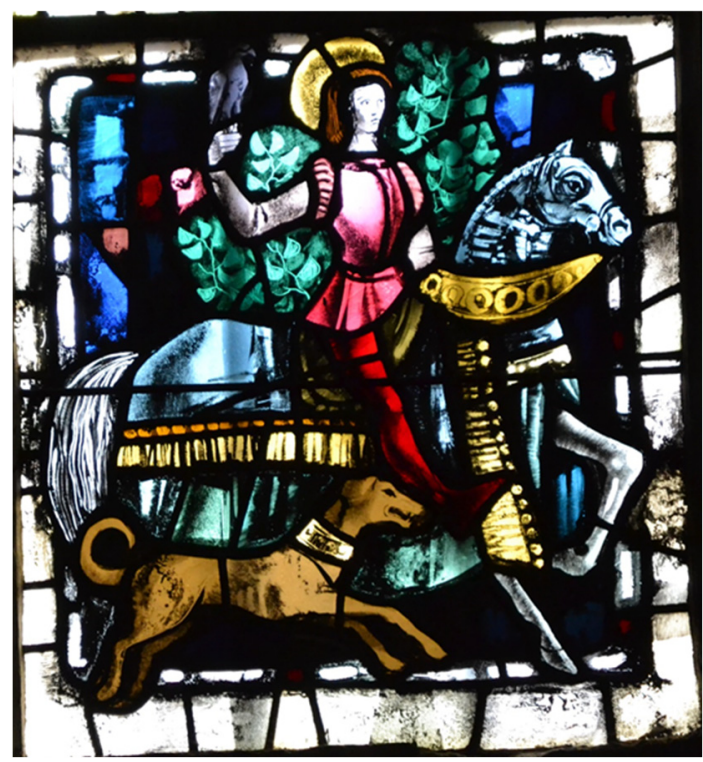

Figure 11. Saint-Lô, Church of Notre-Dame, Saint-Thomas chapel, Life of Saint Thomas window, 1968, detail, Chancellor Thomas hunting. (C) author.



Figure 12. Saint-Lô, Church of Notre-Dame, Saint-Thomas chapel, Life of Saint Thomas window, 1968, detail, Chancellor Thomas leading troops into battle. (C) author. 


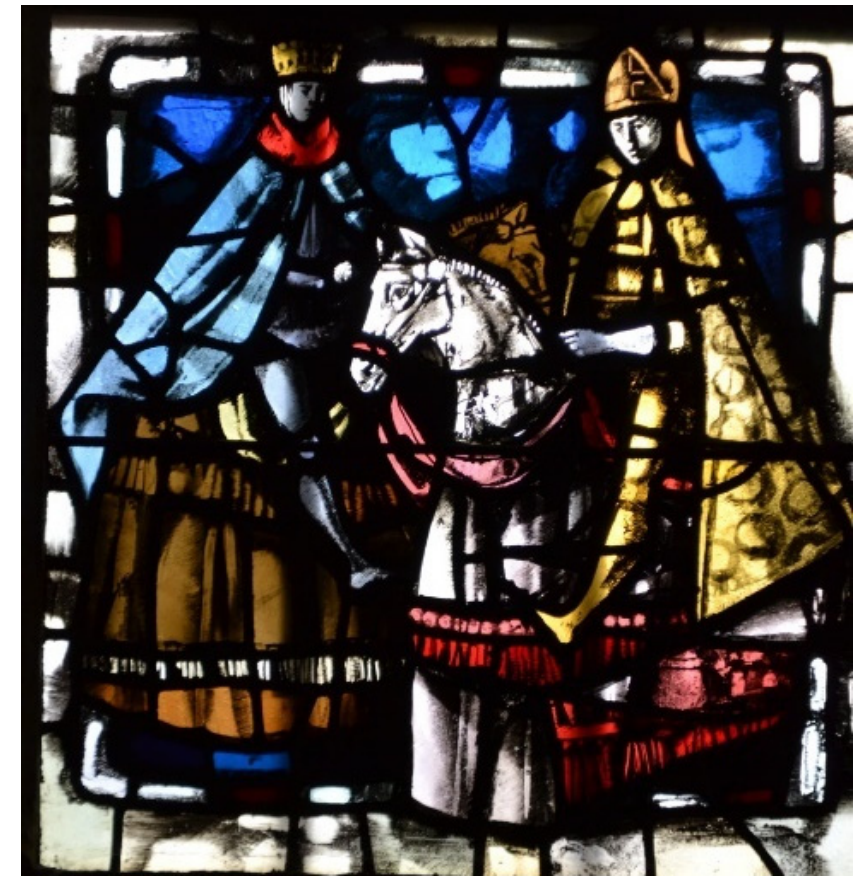

Figure 13. Saint-Lô, Church of Notre-Dame, Saint-Thomas chapel, Life of Saint Thomas window, 1968, detail, Meeting of Henry II and Thomas at Fréteval. (C) author.

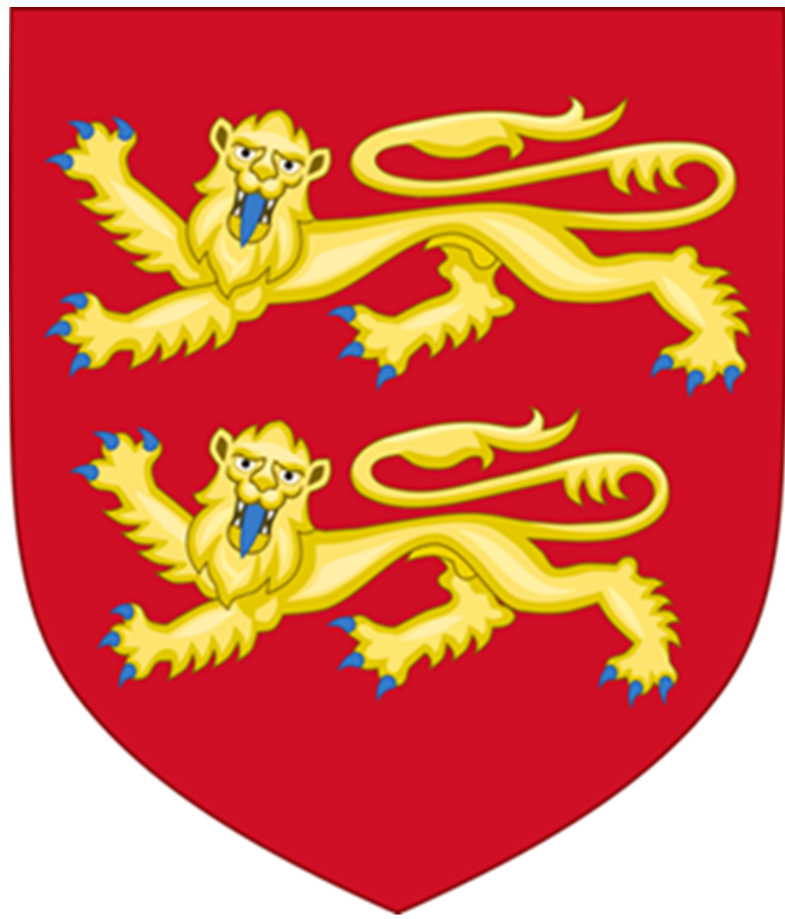

Figure 14. Heraldic Insignia of Normandy. (c) Sodacani, Wikimedia Commons. https: / commons. wikimedia.org/w/index.php?curid=11504651 (accessed on 12 September 2021). 
The window's final lancet invites multiple interpretations. Its inclusion of a king recalls Henry II's many penitential foundations throughout Normandy, an association echoed in the proliferation of ecclesiastical structures which decorate the window's tracery lights (Figures 10 and 18). Additionally, one might suppose the church building to reference Canterbury. The scene of course also recalls archbishop Thomas's passage through SaintLô and his exchange with the masons regarding their church-in-progress which would number among the earliest ecclesiastical dedications to the martyred prelate. The prominent inclusion of a bishop in the background adds strength to this interpretation in that the land upon which Saint-Lô 's église Saint-Thomas was built, belonged to the bishop of Coutances, Richard de Bohun, and the church's dedication was performed by Richard's nephew, Reginald fitz Jocelin, the bishop of Bath (Toustain de Billy 1912, pp. 29-32). In a poignant nod to contemporary exigencies, the scene might even function as a metanarrative of Notre-Dame de Saint-Lô's own reconstruction following the 1944 bombardment, which was nearing completion at the time of the current window's installation (Jamelot and Le Meur 2014, pp. 111-31).

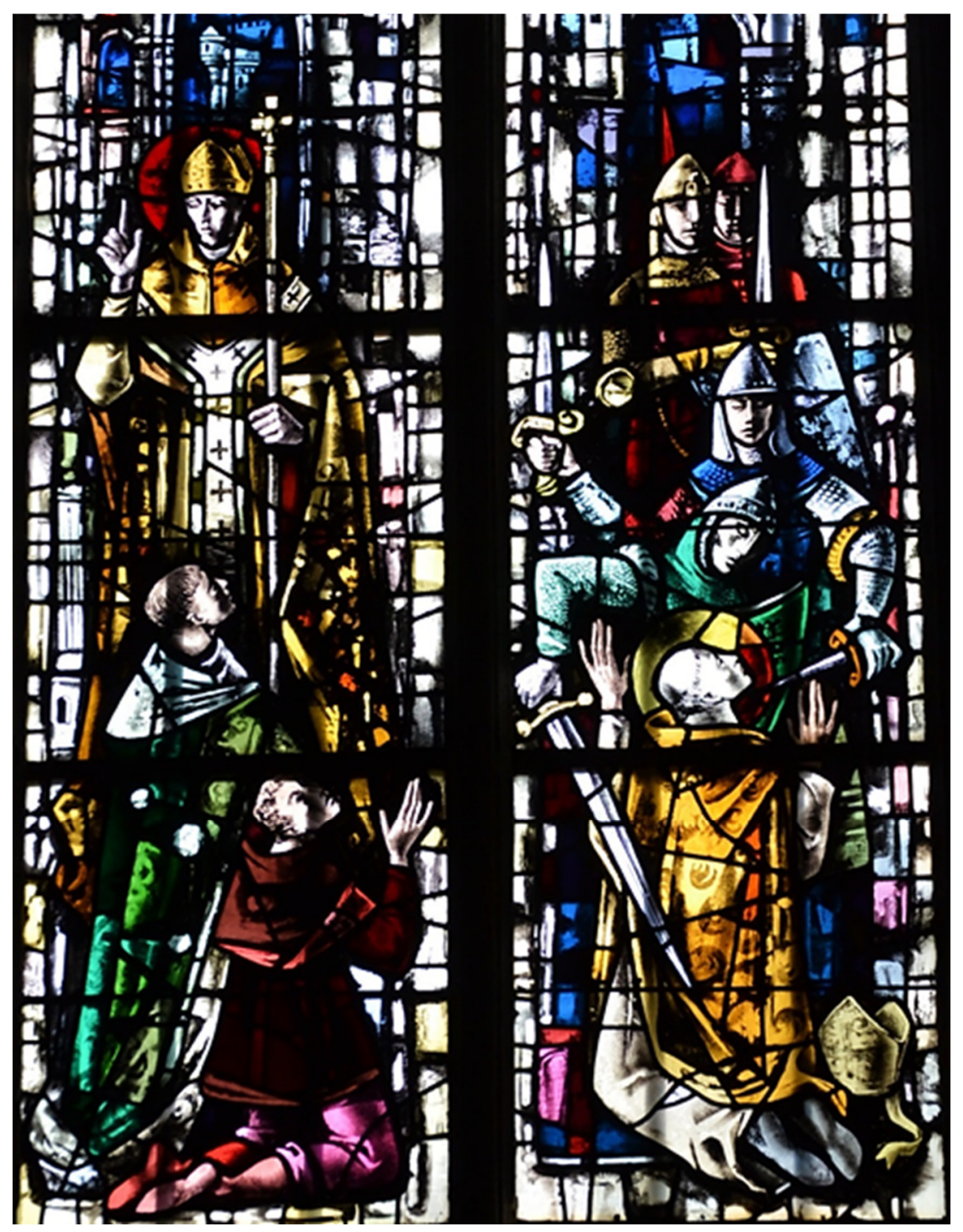

Figure 15. Saint-Lô, Church of Notre-Dame, Saint-Thomas chapel, Life of Saint Thomas window, 1968, detail, Archbishop Thomas returns to Canterbury and Murder of Archbishop Thomas. (C) author. 




Figure 16. Saint-Lô, Church of Notre-Dame, Saint-Thomas chapel, Life of Saint Thomas window, 1968, detail, Christ presents Saint Thomas to God the Father. (c) author. 


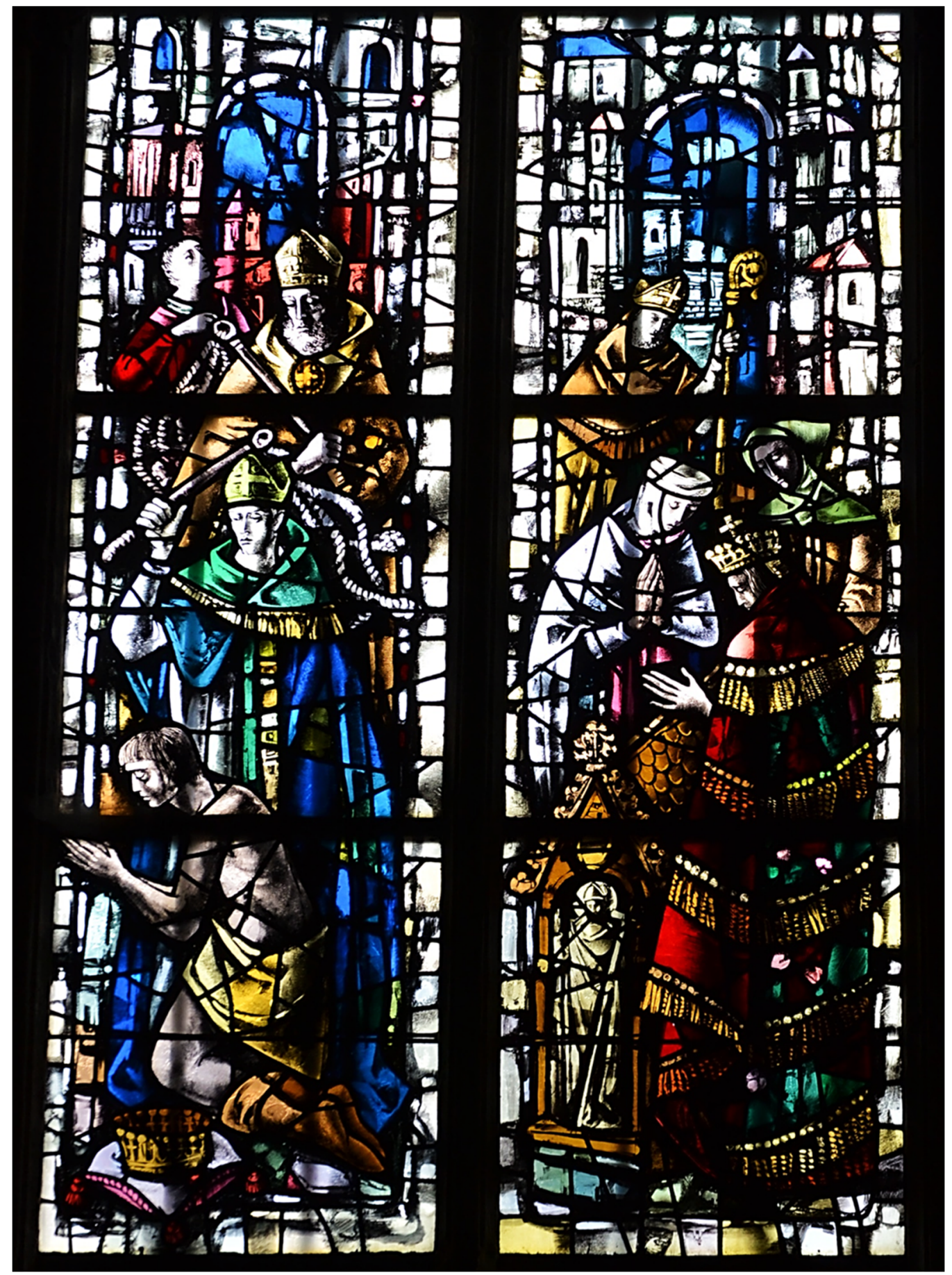

Figure 17. Saint-Lô, Church of Notre-Dame, Saint-Thomas chapel, Life of Saint Thomas window, 1968, detail, Henry II submits to scourging and Veneration of Saint Thomas. (C) author. 




Figure 18. Saint-Lô, Church of Notre-Dame, Saint-Thomas chapel, Life of Saint Thomas window, 1968, detail, tracery containing depictions of churches and other architectural structures. (C) author.

\section{Conclusions}

To the recurrent medieval and postmedieval evocations of Thomas Becket in Saint-Lô can be added others. In Coutances cathedral, a medieval chapel and narrative window devoted to Becket are complemented by an elaborate gothic revival altar also dedicated to the saint. The altar, commissioned in the aftermath of an epidemic of sweating sickness, depicts Saint Thomas flanked by Saints Sebastian and Roch as a trio of powerful healing saints, thus recalling Thomas's medieval fame as a healer, a reputation fueled by the efficacy—and accessibility—of his miraculous water (Neveux 2012; Sigal 2001; Jordan 2009). The thirteenth-century south portal tympanum of Bayeux cathedral featuring Saints Thomas and Stephen converses with a fourteenth-century wall painting in the south transept devoted to Saints Nicholas and Thomas. These late medieval paintings were refurbished in the nineteenth century (Neveux 2016; Juhel 2016; Schlicht and Angheben 2016). A final example, though far from an exhaustive accounting of Becket's visual legacy in Normandy, appears outside Rouen, in a church, originally attached to the leprosarium of Mont-aux-Malades. Rededicated to Saint Thomas in 1174, this church still attends to the spiritual needs of the local population. Restored in the nineteenth century, and outfitted with a new ensemble of Becket windows, it remains physically and symbolically linked to the adjacent clinic — now devoted to gynecology and obstetrics — which has served as a working hospital since its establishment as one of Henry II's penitential foundations (Brenner 2015).

Becket's import for medieval Normandy has long been a focus of scholarly attention. His presence in nineteenth-century Normandy, by contrast, has elicited virtually no discussion. This topic can only be considered in broad terms here, but is certainly crucial for better understanding the saint's reemergence and myriad manifestations. Thomas's significance had diminished on the continent in the early modern period only to be powerfully reinvigorated in the wake of Henry VIII's abolition of the saint's cult in 1538 (Slocum 2019, pp. 170-92; Richardson 2020). In France, the Enlightenment and associated movements towards secular republicanism propelled a decline in religiosity and a particular disaffection with figures like Saint Thomas, who had long been perceived not only 
as stalwart bastions of institutional Catholicism, but specifically of Catholic deference to papal authority. The 1801 Concordat negotiated between Napoleon and Pope Pius VII that reestablished Catholicism in France also inspired a desire to see the French Church more closely connected with the Church of Rome. This movement, known as Utramontanism (literally "beyond the mountains"), sought alignment of the French Church with Roman doctrine and practice and drove much of the revival of French Catholicism. The political failures that attended the monarchic Restoration period (1815-1830), culminating in the July Revolution of 1830 and the installation of the citizen-king Louis-Philippe, only served to re-exacerbate the virulent anticlericalism which had proven such a volatile propellant in the Revolution of 1789. Louis-Philippe's secularist government worked actively to undercut Church influence and authority via stratagems of scientific and technological modernization (Rémond 2007; Gibson 1989).

The Revolution of 1848, which overthrew Louis-Philippe's rationalist regime in favor of the more conservative government of Louis-Napoleon certainly numbers among the most significant factors underpinning the revival of overt religiosity in France during the second half of the century. Louis-Napoleon perceived the Church as a "force for order" and stability (Byrnes 2005, p. 90). The long-embattled institution thus received a strong infusion of governmental support from France's new president, a condition furthered by LouisNapoleon's devout wife Eugénie, particularly following the 1851 coup that made the couple emperor and empress. A flurry of miraculous marian appearances and the broad-based revival of pilgrimage to marian shrines both old and new additionally fueled Catholic and ultramontane support (Byrnes 2005, pp. 89-119). The 1870 Franco-Prussian war that brought down the second empire and established the Third Republic simultaneously discouraged and fueled French religiosity, as France's populace struggled to apprehend the reasons behind its humiliating defeat. In Normandy, a region whose Catholic faith and monarchist leanings remained largely unaltered through the cataclysmic vacillations of French governments, the Church endured those periods of anticlericalism and financial privation while occasionally basking in stretches of governmental approbation and largesse. Throughout the century, the Norman Church sought to stabilize its position and promote its profile upon the shifting sands of Parisian politics. In times of feast as well as famine one finds Saint Thomas visually animating nineteenth-century Normandy as a powerful avatar of Church liberties, Church rights, and Church relevance.

Saint-Lô's 1898 window, Coutances's mid-century altar, Bayeux's restored wall paintings, and Mont-aux-Malades' stained glass ensemble all gave topical expression to the European-wide vogue for works executed in the gothic style. This artistic movement was propelled by broadly based sentiments of patriotism and nationalism that sought inspiration in the indigenous visual languages of its own architectural history, rather than incongruous classical appropriations of Greco-Roman building types. In Normandy, one might interpret the confluence of Becket imagery realized in medievalizing styles as a sort of imbricated historicism. If the revival of gothic forms articulated the region's own medieval culture, Thomas Becket, in his ancestry, historical importance, and ecclesiastical significance, tangibly embodied a time when Normandy - the preferred governmental and residential terrain of Henry II-marked the apex of the region's primacy on the European stage. One specific catalyst for the profusion of works devoted to Becket in nineteenthcentury Normandy may reside in the 1825 publication of Augustin Thierry's History of the English Conquest by the Normans, in which the author identified Thomas not as a Norman, but an Anglo-Saxon, who, in the words of Nicholas Vincent, "defended the liberties of the English people against the tyranny of a foreign king" (Vincent 2007, p. 13). ${ }^{17}$ While quickly discredited in scholarly circles, Becket's misidentification as Anglo-Saxon lived on in popular culture well into the twentieth century, thanks to the many editions of Thierry's own text and the repetition of Thierry's racial attribution in a broad range of artistic productions, including Jean Anouilh's play Becket or The Honor of God and the eponymous 1964 blockbuster film based upon Anouilh's text (Anouilh 1960; Glenville 1964). The flurry of 
nineteenth-century Norman paintings, windows, and sculptures dedicated to Saint Thomas may have comprised in part an effort to reclaim the martyred archbishop for Normandy.

In the thirteenth century Becket's status as a "national saint" was claimed by France as well as England. Nowhere in France was this hagiographic appropriation more enthusiastically embraced than Normandy, the home of Thomas's parents, the region in which Chancellor Thomas appeared often in life as Henry's favored companion and, in death, as that king's saintly protector. Though part of France since its conquest by Philip Augustus, this region had long existed as the hereditary domain of the dukes of Normandy and, from 1066 until 1204, as part of the Anglo-Norman realm. I have argued elsewhere that in those parts of the Angevin Empire which, in the wake of 1204, became conquered French territories, the medieval cult of Thomas Becket served as a site of memory, a tangible connection to the region's historical status as a locus of Anglo-Norman identity and Plantagenet power (Jordan 2016). I propose here that Becket's sustained visibility in nineteenth- and twentiethcentury Normandy evinces his continued importance to that region's Anglo-Norman past. The medieval sites of devotion to Becket's cult remain places of memory articulating, often through visual means, links to Normandy's singular heritage, culture, and religiosity.

To be sure, as lieux de mémoire go, Thomas Becket is no Joan of Arc. His modern artistic appearances are decidedly ecclesiastic and geographically circumscribed but also decidedly distinct and site specific. Coutances cathedral's altar foregrounds the saint's prowess as a healer. At Bayeux, in a cathedral rife with visual testaments to episcopal authority - the gothic gallery of kings was here recast as a gallery of bishops-Thomas appears as the exemplar and martyr par excellence. Back at Saint-Lô, a 1960s window, mirroring its 1890s predecessor, proffers a visual résumé of Becket's local and regional significance, both in his early career as Henry's chancellor and in the final weeks of his life. That archbishop Thomas did not actually traverse Saint-Lô on his return to Canterbury is beside the point. In the spaces between hagiolatry, history, and memory, this urban legend, reified in medieval dedications, perpetuated in modern paintings, windows, and street signs, retains a seminal import. ${ }^{18}$ In Saint-Lô, Coutances, Bayeux, and Mont-auxMalades, new works of art, placed in the immediate locus and aura of their medieval counterparts, construct a material linkage between this uniquely protean saint and the distinctive regional history in which he played so high-profile a part.

Funding: The archival work for this project was completed during 2015-2016. I am grateful to the Department of Comparative Cultural Studies and the College of Arts and Letters at Northern Arizona University for supporting the sabbatical that made this research possible.

Institutional Review Board Statement: Not applicable.

Informed Consent Statement: Not applicable.

Data Availability Statement: Not applicable.

Acknowledgments: I am extremely grateful to Jacky Brionne and Véronique Goulle, archivists of the Archives diocésains de Coutances and the Archives municipales de Coutances respectively, for their assistance and for sharing with me their extensive knowledge of Saint-Lô and its diocese. I would also like to thank Lisa Matz of the Musée Quesnel-Morinière in Coutances, the archivists, librarians, and staff of the Archives départementales de La Manche and the librarians and staff of the médiathèques of Coutances and Grandville.

Conflicts of Interest: The author declares no conflict of interest.

\section{Notes}

Bishop Reginald was himself elected archbishop of Canterbury in 1191, though he died before he could assume that dignity (Barlow 1986, pp. 271-72). Students of medieval art know Reginald fitz Jocelin as having commissioned a very early reliquary pendant, originally containing Saint Thomas's blood and pieces of his bloody garments, which he gifted to Margaret of Navarre, queen of Sicily. The gold pendant identifies Reginald and Margaret by name and depicts queen Margaret receiving the bishop's blessing. Images and pertinent bibliography appear in De Beer and Speakman (2021, p. 98, Figure 3.14, and 251, n. 54). 
2 I have found no documentation of the second Becket church's decoration, but a passing reference suggests it contained historiated windows. Jacqueline (1941, p. 50), discussing the planned destruction of stained glass windows in Notre-Dame containing imagery deemed offensive to Revolutionary sensibilities, states that "Le même traitement devait être infligé, pour le même motif, aux vitrages des trois croisées de l'église Saint-Thomas." Archival records pertaining to this Becket church, together with the extensive archives devoted to the fabric of its medieval predecessor, were destroyed during World War II.

3 I have traced the dedication to Saint George back as far as 1638. The town of Saint-Lô comprised a medieval holding of the bishops of Coutances, whose cathedral also retains evidence of veneration to Saints Thomas and George (Jordan 2016, p. 202). Devotion to Saint George in the diocese of Coutances can be dated to the eighth century, when the saint's relics miraculously appeared on the coast near Cherbourg (Jordan 2016, p. 202). Notre-Dame's unusal layout resulted from a confluence of geography and preexisting structures. Its northern side abutted Saint-Lô's ancient chateau, which precluded any lateral expansion in that direction. The clergy subsequently purchased a row of houses to the south, facing onto what is today the rue Henri-Amiard. This street runs along the dramatic dropoff of the rocky outcropping upon which medieval Saint-Lô was built. In order to make the most of the limited space available for expansion, Notre-Dame's builders enlarged the choir up to the edge of the street, following the street's own irregular profile.

4 Delauney (1864, p. 130) cites the presence of relics of Saints Thomas and Vincent de Paul "renfermées avec leur authentiques dans deux petits reliquaries de forme ovale, attachés à la boiserie de l'autel Saint-Thomas."

5 According to Delauney (1864, pp. 111-12), the Catholic clergy of Notre-Dame were compelled to "share" the church with their Protestant occupiers with separate times allocated for Catholic mass and Protestant services. Jacqueline (1975, p. 49) cites a 1676 visit to Notre-Dame by the bishop of Coutances, Charles-François de Loménie de Brienne, who ordered "que les vitres de l'église et chapelles seront réparées et nettoyées et que description sera faite ... de la vitre qui se trouve dans la chapelle Saint-Georges." It is not clear, however, whether the bishop was referring specifically to the window above the altar, or to one of the other windows along the south side of the church, several of which still retain fifteenth- and sixteenth-century glass. In the second year of the Terror, a regional administrator noted the presence, "dans presque tous les vitrages, des personnages representant l'ancien regime ou le fanatisme," and recommended "le changement en ver (sic) ordinaire" (Jacqueline 1975, pp. 49-50). Writing in 1857, Abbé Delauney, former vicar of Notre-Dame, observed that many windows contained well-preserved panels of old glass, but that most had been displaced to create consolidated windows. Discussing the work of glaziers hired after the Revolution, Delauney laments that "Il n'est pas difficile de se faire une idée de la manière dont ils procédèrent. J'ai vu, il y a 30 ans dans un coin de l'église, des morceaux de vitres cassées parmi lesquelles se trouvaient beaucoup de fragments de verre peint provenant de ces réparations inintelligentes" (Delauney 1864, p. 126.) On the recent condition of the stained glass of Saint-Lô, see Callias Bey and David (2006, pp. 152-64).

6 I am grateful to Danielle Rault-Verprey, of the Musée Quesnel-Morinière, for confirming the painting's presence in the museum and providing me with details regarding its size and condition. Danielle Rault-Verprey, 2015, e-mail message to author, November 29. According to LeClerc (1931a, p. 39), it was transferred to the Musée de Saint-Lô in 1930. I could not determine when the painting moved to the Musée Quesnel-Morinière in Coutances, but its transfer must have predated the 1944 bombardment of Saint-Lô. Mme. Rault-Verprey confirmed that no information about the painting exists beyond the minimal description found in the museum's inventory.

$7 \quad$ LeClerc (1931a, p. 39) dates the painting to 1850, but the painting itself is undated.

8 LeClerc (1931b, p. 253) observes that at some indeterminate date the painting had been stored under Notre-Dame's north tower, but that it had been recently moved to the "Chapelle des Fonts, en attendant une nouvelle destination." The article concludes on a note of regional pride, describing the work as, "une toile intéressante, en dehors même du sujet qu'elle traite et qui se rattache à l'histoire de la Normandie: elle ornait l'église Notre-Dame et elle a pour auteur Basile Quesnel, un artiste coutançais".

9 The full quotation reads, "Il me semble qu'au milieu même de l'atrocité du crime, l'artiste aurait pu conserver à ses acteurs quelque trait qui rappelât la noblesse de leur origine, quelque chose de moins vulgaire; la scène n'y aurait pas perdu de son intérêt, le contraste aurait été plus frappant: mais allez donc reconnaître de grands seigneurs sous ces figures patibulaires" (Delauney 1864, pp. 120-21).

10 The money to execute the window was bequeathed to Notre-Dame by Mme. Duhamel (née Giffard). The chapel had belonged to the Giffard family since 1785 (Delauney 1864, p. 40; Jacqueline 1975, p. 37). Félix Gaudin's extensive career as a stained glass artist together with his profound intellectual and cultural contributions to the French gothic revival have been deftly explored by Jean-François Luneau (2006).

11 I am indebted to my husband, Dr. Joseph Boles, for bringing the eBay offering of this print to my attention. The print is a reproduction and appears to have come from a French journal that I have, as yet, been unable to identify. The plate identifies the issue of the journal as "2e Serie-4e Année".

12 Barlow (1986, pp. 123-24) says that Thomas and his clerks expressed a preference to go to Pontigny when they met with Alexander III upon their arrival in Sens in 1164; Duggan (2004, pp. 95-96) states that, at Pontigny, Thomas wore a monastic habit "blessed for him by the pope ... but did not make a monastic profession." According to Alan of Tewkesbury's rendition of events, after Thomas made his case before Alexander III and presented him with a copy of the Constitutions of Clarendon, the 
pope told Thomas he had decided " ... to commend you to be trained by the poor of Christ, that is the abbot of Pontigny, and his men. Not ... to be trained in splendour but in simplicity, as befits an exile and an athlete of Christ" (Staunton 2001, p. 134).

LeClerc (1931a) does not identify the predella scenes. He describes the tracery lights as being filled with symbols corresponding to the three phases of Thomas's life depicted in the large lancets (p. 41). On Thomas's interactions with the Cistercian monks of Pontigny during his exile see, Barlow (1986, pp. 157-58). Thomas moved to the Benedictine abbey of Saint Colomba in October 1166, after Henry II threatened the Cistercian establishments in England with retribution if the monks of Pontigny continued to assist him.

15 Magnússon reproduces the original Icelandic text alongside his English translation.

16 I am indebted to John Jenkins for drawing the connection between the scene in Gaudin's window and the Icelandic Saga and to Rachel Koopmans for the reference to Caxton's Golden Legend. LeClerc (1931a, pp. 40-41) interpreted the chasuble's red color as symbolic of the archbishop's martyrdom, which additionally calls to mind Thomas's invocation of the Virgin at the moment of his death.

17 Thierry's analysis of the Thomas Becket-Henry II dispute, which appeared in his Histoire de la Conquête de l'Angleterre par les Normands, is now available as a freestanding publication (Thierry 2002). On the revival of interest in Thomas Becket in France see (Simmons 1990, pp. 117-24; Vincent 2016, pp. 99-100).

18 The story of Archbishop Thomas's passage through Saint-Lô is recounted, without qualification, in a 2012 publication devoted to the town's history and draws a parallel between the destruction of the two Saint-Lô Becket churches and the saint's own martyrdom (Bertin and Viart 2012, p. 25).

\section{References}

Anouilh, Jean. 1960. Becket or The Honor of God. Translated by Lucienne Hill. New York: Riverhead Books.

Barlow, Frank. 1986. Thomas Becket. Berkeley: University of California Press.

Becket, 1964, Peter Glenville, director. Los Angeles: Paramount Pictures.

Bertin, Philippe, and Jean-Paul Viart. 2012. Dicocité illustré de Saint-Lô. Paris: R \& Co.

Blin, Jean-Pierre. 2017. Max Ingrand (1908-1969): Un peintre verrier dans la Normandie de la Reconstruction. In Modernité Sacrée: Aspects du Renouveau de l'art Sacré en Normandie (1920-1960). Edited by Claire Maingon et Nicolas Coutant. Mont-Saint-Aignan: Presses Universitaires de Rouen et du Havre, pp. 137-52.

Borenius, Tancred. 1932. Saint Thomas Becket in Art. London: Methuen \& Co. Ltd.

Brenner, Elma. 2015. Leprosy and Charity in Medieval Rouen. Woodbridge: The Boydell Press.

Brisac, Catherine. 1975. Thomas Becket dans le vitrail français au début du XIIIe siècle. In Thomas Becket: Actes du colloque International de Sédières. Edited by Raymonde Foreville. Paris: Beauchesne, pp. 221-31.

Byrnes, Joseph F. 2005. Catholic and French Forever: Religious and National Identity in Modern France. University Park: Pennsylvania State University Press.

Callias Bey, Martine, and Véronique David. 2006. Les Vitraux de Basse-Normandie. Corpus Vitrearum. France-Recensement VIII. Rennes: Presses universitaires de Rennes.

Daniel, Jacques-Louis. 1855. Mandement de Monseigneur l'Evêque de Coutances et d'Avranches a l'occasion de la Définition Dogmatique de l'Immaculée Conception de la Très-Sainte Vierge. Coutances: n.p.

De Beer, Lloyd, and Naomi Speakman. 2021. Thomas Becket: Murder and the Making of a Saint. London: The British Museum Press.

Delauney, L'Abbé. 1864. Notice sur l'église Notre-Dame de Saint-Lô. Notices, mémoires, et Documents de la Société d'Architecture et d'Histoire Naturelle de la Manche 2: 59-147.

Duggan, Anne. 2000. The Official Record of Henry II's Reconciliation at Avranches, 21 May 1172. The English Historical Review 115: 643-58. [CrossRef]

Duggan, Anne. 2004. Thomas Becket. London: Arnold Publishers.

Ellis, F.S. 1910. The Golden Legend or Lives of the Saints Englished by William Caxton. Edited by Frederick Startridge Ellis. London: J. M. Dent and Sons, vol. 2, Available online: https://sourcebooks.fordham.edu/basis/goldenlegend/GoldenLegend-Volume2.asp (accessed on 1 September 2021). First published 1483.

Foreville, Raymonde. 1973. Les Origines normandes de la famille Becket et le culte de saint Thomas en Normandie. Mélanges offerts à Pierre Andrieu-Guitrancourt. L'Année Canonique 17: 433-80.

Foreville, Raymonde. 1975. Le Culte de Saint Thomas Becket en Normandie. In Thomas Becket: Actes du colloque International de Sédières. Edited by Raymonde Foreville. Paris: Beauchesne, pp. 135-52.

Fournée, Jean. 1995. Les Lieux de culte de Saint Thomas Becket en Normandie. Annales de Normandie 45: 377-92. [CrossRef]

Gibson, Ralph. 1989. A Social History of French Catholicism, 1789-1914. London: Routledge.

Hayes, Dawn Marie. 2004. Body as Champion of Church Authority and Sacred Place: The Murder of Thomas Becket. In 'A Great Effusion of Blood?': Interpreting Medieval Violence. Edited by Mark D. Meyerson, Daniel Thiery and Oren Falk. Toronto: University of Toronto Press, pp. 190-215.

Holweck, Frederick. 1910. Immaculate Conception. In The Catholic Encyclopedia. New York: Robert Appleton Company, Available online: http:/ / www.newadvent.org/cathen/07674d.htm (accessed on 15 June 2021). 
Jacqueline, Bernard. 1941. Les Vitraux anciens de Notre-Dame de Saint-Lô. Notices, Mémoires, et Documents de la Société d'Architecture et d'Histoire Naturelle de la Manche 53: 45-64.

Jacqueline, Bernard. 1975. Histoire de l'église paroissiale Notre-Dame de Saint-Lô. Revue du Département de la Manche 17: 3-42.

Jamelot, Daniel, and Pierre Yves Le Meur. 2014. Notre-Dame de Saint-Lô: Neuf siècles de Bâtisseurs. Saint-Lô: L'Association des amis des orgues en pays saint-lois.

Jordan, Alyce A. 2009. The 'Water of Thomas Becket': Water as Medium, Metaphor and Relic. In The Nature and Function of Water, Baths, Bathing and Hygiene from Antiquity through the Renaissance. Edited by Cynthia Kosso and Anne Scott. Leiden: Brill, pp. 479-500.

Jordan, Alyce A. 2016. The St Thomas Becket Windows at Angers and Coutances: Devotion, Subversion, and the Scottish Connection. In The Cult of St Thomas Becket in the Plantagenet World. Edited by Paul Webster and Marie-Pierre Gelin. Woodbridge: Brill, pp. 171-207.

Juhel, Vincent. 2016. Les Peintures murales du Moyen Âge. In Bayeux: Joyau du Gothique Normand. Edited by Jean-Claude Boulanger and François Neveux. Strasbourg: La Nuée Bleue/Éditions du Quotidien, pp. 253-65.

Koopmans, Rachel. 2014. Early Sixteenth-Century Stained Glass at St. Michael-le-Belfrey and the Commemoration of Thomas Becket in Late Medieval York. Speculum 89: 1040-100. [CrossRef]

Koopmans, Rachel. 2020. Gifts of Thomas Becket's Clothing Made by the Monks of Canterbury Cathedral. Journal of the British Archaeological Association 173: 39-60. [CrossRef]

Kselman, Thomas A. 1983. Miracles and Prophecies in Nineteenth-Century France. New Brunswick: Rutgers University Press.

LeClerc, R. 1931a. Notre-Dame de Saint-Lô. Notices, Mémoires, et Documents de la Société d'Architecture et d'Histoire Naturelle de la Manche 43: $1-79$.

LeClerc, R. 1931b. Un Tableau à remettre en honneur. Notices, Mémoires, et Documents de la Société d'Architecture et d'Histoire Naturelle de la Manche 43: 253.

LeClerc, R. 1932. Le Vieux Saint-Lô qui n'est plus: L'Église Saint-Thomas. Annuaire du department de la Manche 101: 9-22.

Luneau, Jean-François. 2006. Félix Gaudin: Peinture-Verrier et Mosaïste, 1851-1930. Clermont-Ferrand: Presses Universitaires Blaise Pascal.

Magnússon, Eríkr. 2012. A Life of Archbishop Thomas Becket in Icelandic. Edited by Eríkr Magnússon. Translated by Eríkr Magnússon. Cambridge: Cambridge University Press, vol. 1. First published 1875.

Neveux, François. 2012. Hugues de Morville et l'épiscopat normand des XIIe-XIIIe siècles. In La Cathédrale de Coutances. Colloque de Cerisy (8-10 Octobre 2009). Edited by Françise Laty, Pierre Bouet, Gilles Désiré dit Gosset and Alexandre Poirier. Bayeux: Orep Éditions, pp. 47-55.

Neveux, François. 2016. La Métamorphose gothique. In Bayeux: Joyau du Gothique Normand. Edited by Jean-Claude Boulanger and François Neveux. Strasbourg: La Nuée Bleue/Éditions du Quotidien, pp. 50-61.

Nilgen, Ursula. 2000. Thomas Becket en Normandie. In Les Saints dans la Normandie Médiévale. Colloque de Cerisy-la-Salle (26-29 Septembre 1996). Edited by Pierre Bouet and François Neveux. Caen: Presses Universitaires de Caen, pp. 189-204.

No Author. 1936. Anciens autels en bois sculpte de la région Saint-Loise. Notices, Mémoires, et Documents de la Société d'Architecture et d'Histoire Naturelle de la Manche 48: 158-59.

Petit, Yves. 1999. Thomas Becket et la Normandie. Condé-sur-Noireau: Éditions Charles Corlet.

Plum, Gilles. 1994. Saint-Lô: La Reconstruction. \#62 Itinéraires du Patrimoine. Alençon: Imprimerie Alençonnaise.

Poncelet, Albert. 1910. St. Ildephonsus. In The Catholic Encyclopedia. New York: Robert Appleton Company, Available online: http:/ / www.newadvent.org/cathen/07649b.htm (accessed on 1 September 2021).

Rémond, René. 2007. L'Anticléricalisme en France de 1815 à nos jours. Paris: Fayard.

Richardson, Carol M. 2020. Saint Thomas at the English College in Rome. Journal of the British Archaeological Association 173: 18-203. [CrossRef]

Schlicht, Markus, and Marcello Angheben. 2016. La Sculpture gothique. In Bayeux: Joyau du Gothique Normand. Edited by Jean-Claude Boulanger and François Neveux. Strasbourg: La Nuée Bleue/Éditions du Quotidien, pp. 234-51.

Shalem, Avinoam. 2016. The Chasuble of Thomas Becket. Edited by Avinoam Shalem. Munich: Hirmer Publishers.

Sigal, Pierre André. 2001. Naissance et premier développement d'un vinage exceptionnel: L'eau de saint Thomas. CCM 44: 35-44. [CrossRef]

Simmons, Clare A. 1990. Reversing the Conquest: History and Myth in Nineteenth-Century British Literature. New Brunswick: Rutgers University Press.

Slocum, Kay Brainerd. 2019. The Cult of Thomas Becket: History and Historiography through Eight Centuries. London: Routledge.

Spear, David S. 1998. Power, Patronage, and Personality in the Norman Cathedral Chapters, 911-1204. In Anglo-Norman Studies. Proceedings of the Battle Conference in Dublin, 1997. Edited by Christopher Harper-Bill. Woodbridge: The Boydell Press, vol. 20, pp. 205-21.

Staunton, Michael. 2001. The Lives of Thomas Becket. Manchester: Manchester University Press.

Thierry, Augustin. 2002. Vie et mort de Thomas Becket. Paris: La Table Ronde.

Thurston, Herbert. 1910. Chasuble. In The Catholic Encyclopedia. New York: Robert Appleton Company, Available online: https: / / www.newadvent.org/cathen/03639a.htm (accessed on 3 September 2021).

Toustain de Billy, René. 1912. Mémoires sur L'histoire du Cotentin et de ses Villes: Villes de Saint-Lô et Carentan. Saint-Lô: Felix le Tual. 
Vincent, Nicholas. 2007. Introduction: Henry II and the Historians. In Henry II New Interpretations. Edited by Christopher Harper-Bill and Nicholas Vincent. Woodbridge: The Boydell Press, pp. 1-23.

Vincent, Nicholas. 2016. Thomas Becket. In Making and Remaking Saints in Nineteenth-Century Britain. Edited by Gareth Atkins. Manchester: Manchester University Press, pp. 92-111.

Voragine, Jacobus da. 1993. The Golden Legend. Translated by William Granger Ryan. Princeton: Princeton University Press, vol. 1. Webster, Paul. 2016. Introduction. The Cult of St Thomas Becket: An Historiographical Pilgrimage. In The Cult of St Thomas Becket in the Plantagenet World, c. 1170-c. 1220. Edited by Paul Webster and Marie-Pierre Gelin. Woodbridge: The Boydell Press, pp. 1-24. 